\title{
The quest for medieval deserted villages in the Strzelin Heights region (Wzgórza Strzelińskie) in Silesia. Preliminary results
}

\author{
Krzysztof Fokt - Maria Legut-Pintal
}

\begin{abstract}
Abstrakt
Překládaná studie shrnuje výsledky interdisciplinárního výzkumu realizovaného autory v letech 2007-2014. Předmětem zájmu byly pozůstatky zaniklých středověkých vsí, tedy skupina výrazných archeologických památek dlouho opomíjená tradičním polským bádáním (kap. 1). Hlavním cílem výzkumu, jenž byl zahájen již roku 2007 v oblasti dolnoslezského střelínského masivu, bylo změnit tuto nepříznivou situaci a vyhledat dobře uchované relikty zaniklých vsí známých z písemných pramenů (kap. 2). Náplní studie je zasazení zkoumaných vsí do širšího historického kontextu (kap. 3) a prezentace dvou etap výzkumu (kap. 4-5).
\end{abstract}

\begin{abstract}
In the present paper, the results of archaeological investigations conducted in the years 2007-2014 by the authors will be briefly presented and summarized. In fact, two separate research undertakings by two authors representing different institutions, but following joint research agenda, were merged in the following text into one single history of investigation, focused on a group of archaeological sites hitherto neglected in the Polish research tradition (see below, part 1), i.e. remains of deserted villages from the late Middle Ages. The main goal of the research undertakings which began in 2007 in the Strzelin Heights region was to change this inconvenient situation by discovering well-preserved material remains of some villages known from written evidence (see below, part 2). In order to place the abandoned villages of the Strzelin Heights into respective, appropriate socio-spatial framework, a short analysis of their historical context was also made (part 3). Eventually, two stages of the fieldwork were presented and commented (parts 4-5).
\end{abstract}

Klíčová slova: Slezsko - Střelínské pohoří - středověk - zaniklé vsi

Key words: Silesia - Strzelin Heights (Wzgórza Strzelińskie) - Middle Ages - deserted villages

DOI: $10.14712 / 25707213.2018 .2$

\section{Remarks on the hitherto Polish research on late medieval deserted villages}

Late medieval deserted villages in Poland have never become an autonomous subject of archaeological research, as it happened in the states neighboring with Poland to the west and south. In fact it should be even stated - despite optimistic opinions of some Polish scholars (Poklewski 1987, 32; Śriętostawski 2011, 5; Żemigała 2011, 11) - that there has been no planned and conceit archaeological investigation of late medie- val rural milieus in Poland. If any archaeological sites related to late mediaeval rural settlements were excavated at all, these were cases of research-driven projects focused actually on early Middle Ages, excavations concentrated on late medieval fortified seats or emergency documentations of accidentally discovered material remains from the past (see the reviews of research by Kajzer 1996, 161-172, passim; ¿̇emigała 2011; Poklewski-Koziełt 2011; Fokt 2012, 31, 35, 39, 41, 42, 64-65, 71-109).

There were various reasons and circumstances which resulted in neglecting the late medieval rural sites in 
Poland. In general, rural settlements younger than the mid-13th century have never attracted any special concern of Polish archaeologists. Polish medieval archeology has been for a long time almost exclusively focused on early Middle Ages, displaying no concern to other sites from later periods than the urban and fortified ones. In the areas incorporated to Poland after World War II yet another factor must be taken into consideration - for a long time their new inhabitants did not feel much at home there and thus they did not display any particular motivation to investigate local late medieval or early modern remains, generally treated as "German". There was also no such personality in Polish archaeology, as Vladimír Nekuda in Moravia or Zdeněk Smetánka in Bohemia, who would launch huge investigation of medieval villages and thus attract attention of both scholars and broader public. Only recently the attitude towards the material remains of late medieval villages began to change, leading to wider acceptance of the need to investigate such sites by the means of archeology. Despite that, general view of results hitherto obtained in Poland differs a lot from what may be said about situation in Germany or Czech Republic. Among the researches of late medieval remnants of rural settlements conducted in Poland there have been neither - except from some minor activities on a few sites (see Fokt 2012, 84-89; Hensel-Hilczer-Kurnatowska - Łosińska 1995, 161-162; see also further, by Sudetes and Carpathian Mts.) - excavations of deserted villages, nor extensive rescue excavations of existing village cores. What has been researched are translocated village cores, remnants of some auxiliary settlements, elements of infrastructure (streets, fords, watermills) and spurs of non-agrarian production. Moreover, there is no chance for change of that situation as long as perspectives of rural archaeology in Poland would remain dependent only from actual plans of infrastructural investments across the country. In such case, "typical" deserted medieval villages will still remain beyond the interests of Polish archaeologists.

This statement is especially true when it comes to the deserted villages of the mountainous areas of southern Poland, which rather cannot count on being involved in any program of rescue excavation. Only a few of such sites have been subdued to any sort of archaeological research. Just as in case of such sites researched in the lowlands, most of those discovered in the Sudetes and Carpathian Mts. were not deserted late medieval villages sensu strictiori - that is rural complexes grounded or at least reorganized in the late Middle Ages (2nd half of 13th - beginning of the 16th centuries) - but abandoned or translocated settlements originating from the previous period (Sobótka, site 4: Geschwendt 1922; Domańs- ki 2002, 80, nr 180; Fokt 2012, 87, table III.1; Dubiecko, site 3: Parczeroski 2007, 26-30; Frydman: Niemiec 2012, 13-14). Only in Zachełmie in Giant Mts. (Karkonosze); (cf. Fokt 2012, 88 and archival data quoted there), Głębinów in the former episcopal duchy of Nysa/Neisse (Romiński 1969, 19; Fokt 2012, 87, tab. III.1) and by Falsztyn in the Spisz region (Tobiasz 1964; Parczewski 1974, 70, annot. 4) some parts of deserted or translocated village cores of late medieval foundation were identified by archaeologists or at least archaeologists somehow - by participation (Falsztyn) or subsequent documentation of discoveries of non-professionals (Zachełmie) - contributed to their investigation.

\section{Deserted medieval villages in the northern part of the Strzelin Heights as potential object of investigation}

An idea to launch a field research project on deserted medieval villages of one of Silesian microregions was born as a reaction to the unsatisfying state of research, briefly described above. The number of regions to choose from was not very high, as the density of deserted villages in Silesia is not comparable to the situation in England, Bohemia, Moravia or Lower Austria. The choice of Strzelin Heights region was caused by three factors potentially advantageous from the viewpoint of future field research (Fig. 1). Firstly, some basic historical inquiry on this region has already been done (Eistert 1935-36; 1937; 1938), which allows to create a preliminary list of deserted villages and premises of their location in field. Secondly, most of the presumed deserted village cores should be looked for in the areas at present covered with forests - which does not guarantee that they will be well preserved, but at least allows not to exclude this possibility a limine. Finally, quite huge density of deserted late medieval settlements in the area of Strzelin Heights, especially in its northern part (at least three deserted villages and one manor on around 22 square kilometers of forested area) makes the search for their relics potentially easier and more effective. Moreover, apart from villages deserted in the late Middle Ages, there are at least two presumable older settlement cores of villages existing up to present times: Pogroda and Gębczyce, to be found in the northern part of Strzelin Heights (see Vug 1890, 285; Brucksch 1926; Fokt 2010, 264-265), at least the latter being situated in woodland.

Abandoned medieval villages of the Strzelin Heights region constitute a unique group of sites especially interesting from the viewpoint of history of rural settlement and economy. They were all located in a highland area most exposed to the risk of low 


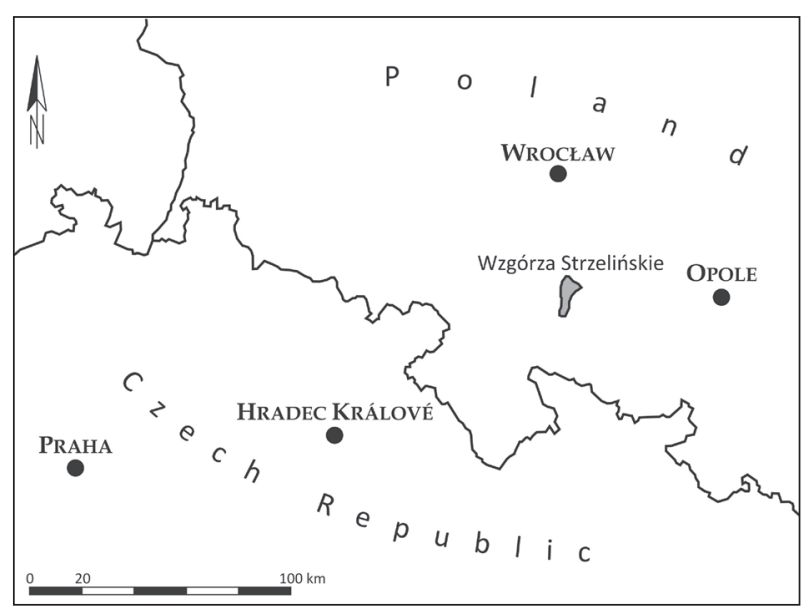

Fig. 1. Location of the Strzelin Heights region (Wzgórza Strzelińskie), by M. Legut-Pintal. - Obr. 1. Poloha Střelínské pahorkatiny (Wzgórza Strzelińskie). Vypracovala: M. Legut-Pintal.

economic efficiency due to the characteristics of geoecosystems in which they existed. The area of Strzelin Heights did not offer the settlers either fertile soils comparable to the loess soils of the neighboring lowlands or flatness of terrain which would facilitate the cultivation of fields and prevent soil from being rinsed off by surface flow. Therefore, the deserted villages of the Strzelin Heights may be treated as a sample for an extreme case study, which could allow us to state to what extent agriculture was profitable in a highland area and with what sort of non-agricultural activities it was supplemented in order to provide subsistence for the inhabitants of the villages and feudal rent for their owners (see Fokt 2010, 265-266).

\section{Historical context of the deserted villages in the northern part of the Strzelin Heights}

All villages that once existed in the highest parts of the Strzelin Heights, at present covered with forests, were probably grounded during the last wave of intensification of rural colonization in the years 1290-1300 (cf. Maleczyński 1960, 396), under the rule of Bolko I the Severe $(+1301)$. Therefore, we would be dealing with the output of the advanced phase of the high medieval rural colonization, taking place yet in the framework of ius Theutonicum, in which both local and immigrant peasant populations were engaged (including the second or even third generation of German settlers, which may be at that time already regarded as native Silesians, especially in the southern part of the country).
The process of high medieval rural colonization of the Strzelin Heights may be roughly divided into three phases. Initially, in the last quarter of the 12th and the 1st quarter of the following century, the outer fringes of the region were being settled rather spontaneously on behalf of the Silesian dukes and nobles. Subsequently, the phase of intensification followed, characterized by introduction of the ius Theutonicum, further increase of the number of villages and consolidation of local dominions both ecclesiastical, represented by the Cistercian monastery of Henryków (see Pater et al. ed. 1991; cf. Dabrowski 1956; Korta 1964, 82-83, passim), and secular, with dominant role of the lords of Strzelin (see Rutkowska-Płachcińska 1965, 39-51). In the final stage - after 1290 , when the region was separated from the Wrocław duchy and became a part of the realm of Bolko I the Severe - the old centre of the lords of Strzelin was replaced by a chartered town of ducal foundation (grounded 1292) and Clarissine convent founded there by Bolko I (1295) joined Henryków monastery as the second monastic institute of the region (cf. Przybytowicz 2016). The nuns from Strzelin were bestowed with land and revenues not only in the town, but also in the closest, northern part of the Strzelin Heights. An important part of the rich donations of Bolko I was the patronage of the parish church in Strzelin, which was responsible for pastoral care of some former knightly possessions as well as of ducal villages, newly founded in the Strzelin Heights - among them, those of special interest for us, which were later abandoned.

Such a structure of the abovementioned parish was not accidental: the late encroachment of Bolko I into the structures of power and settlement of the region forced the duke to use three main tools to underpin his rule in Strzelin and its surroundings. The backbone of the ducal power was, of course, the former domain of the lords of Strzelin, taken over and actively transformed by the duke (see Rutkowska-Ptachcinska 1965, 49-51). Secondly, location of the chartered town Strzelin allowed the ruler to concentrate economic power in his hand. Finally - last, but not least - on behalf of the duke a few new settlements in the northernmost part of the Strzelin Hills were founded. The hypothesis of ducal foundation may be supported directly in case of the *Prążkowo manor, which was in 1299 granted by Bolko I as hereditary possession to the four Prążko brothers (SUB 6, no. 393). A few charters support also indirectly the supposition of ducal foundation in case of the villages Goschwitz and Crossyn, which belonged to the Strzelin Clarissine convent, founded by the abovementioned Silesian duke (SR 2660, 3663). In case of Goschwitz even some payment reserved 
exclusively to the ducal treasury was mentioned in 1332 (SR 5098).

All the above mentioned villages of ducal foundation are known only from documents created in the 13th and 14th centuries and were probably abandoned yet before the end of the 14th century (see Fokt 2010, 265). Among the deserted settlements in the northern part of the Strzelin Heights, only the village (not manor, see Fokt 2010, 264) Buchwald was yet in the 16 th century mentioned as still existing (see Golinski 2007, 13, 22-23). That village was probably of noble foundation, as yet in the 14th century some members of the Samborowice (Tschammer) family were selling a forest called Buchwald, situated between the villages Buchwald and Goschwitz (SR 6696-6698) ${ }^{1}$. In the 15 th and 16 th centuries Buchwald was a part of the Gromnik (Rummelsberg) domain of the noble Czirn family, very influential in this part of Silesia. Also another village in the region, which will be often referred to in this paper, was a part of the Czirn domain: Geppersdorf, today named Gębczyce. All other settlements situated in the part of the region at present covered with forests were probably abandoned much earlier, yet in the 14 th century.

\section{The first stage of the research on Strzelin Heights (2007-2009): the northwestern part of the region}

In the year 2007, the first stage of field research on the abandoned villages on the Strzelin Heights began, launched on behalf of the Institute of Archaeology of the Wrocław University. At this point all attempts to find any relics of the villages Goschwitz, Buchwald, Prążkowo or Crossyn failed (see Fokt 2010, 267). Quite unexpectedly, however, a settlement which could be interpreted as one of the translocated village cores - the one of the village Geppersdorf (at present: Gębczyce) was discovered. The site, although being at present situated within the limits of the village Dębniki, was registered under the num-

1 See also: State Archive (Archiwum Państwowe) in Wrocław, Rep. 121, charters, no. 34 (referred to also by Eistert 1937): siluam Buchwalt inter uillam Gostoncicz et Buchwalt in praedicto Nostro Strelinensi districtu. The name Coztenzcic - which may be also read, according to F. X. Goerlich $(1853,7)$ Costenczit, respectively Gostonczicz or Gosconczicz - mentioned in the source (State Archive in Wrocław, Rep. 132a, charters, no. 5), was erroneously interpreted as the name of another deserted village Costanz by K. Wutke and E. Randt (SR 6696) and as the name of the still-existing village Pogroda (germ. Pogarth) by Gaik et al. 2005, 20. Another corrupt form of the name Goschwitz, in the original charter spelled Coszotiz (State Archive in Wrocław, Rep. 121, charters, no. 2), but sometimes spelled uncorrectly (Gospotus or Cospotiz) after later copies, was misinterpreted as the name of the still existing village Chociwel (Stelmach ed. 1991, no. 807). ber 3 in Gębczyce, as according to the local tradition written down by teacher Brucksch (1926) it should be there that the buildings of Geppersdorf were initially built. The site was subdivided into two parts: site 3A, provisionally identified as remnants of the peasant settlement, and site 3B: the former manor.

The most of the area of the site 3A was in 2007 a meadow upon Ciszek stream (a right tributary of Pogródka), destined to be forested, with little trees already growing there. In the westernmost part of this site, on its turn, thick bush was growing. The site $3 \mathrm{~B}$ - lying round $300 \mathrm{~m}$ to the east of $3 \mathrm{~A}-$ was been at that time, on the contrary, covered with forest. Both parts of the site were subject to sounding excavations in the years 2007-2009, organized on behalf of the Institute of Archaeology of Wrocław University. On the site $3 \mathrm{~A}$ one small sounding trench (II/07) was explored in the year 2007 in its eastern part and two sets of sounding trenches (III/07 with annexes excavated in 2008 and V/09 with annexes) were explored in its central part in the years 20072009 (see Fig. 2).

On the site $3 \mathrm{~B}$ one sounding trench (I/07) was excavated in the northern part of the island interpreted as a rest of a moated site, an assumed fortification "on water" (Wasserburg), in 2007. This little sounding trench was situated on the inner slope of an elevation of ground registered in the northernmost part of the island, as it has been presumed that the elevation could have been a rest of a rampart and expected that, like on many ringforts, rich sequence of cultural layers was probable to reside just behind the line of fortification. A few other trenches were opened on the shore of the pond on which the abovementioned island was situated: the trench no. IV/09 to the northeast of the island, where relics of a watermill were expected, and the trenches VI-VII/09 with annexes directly to the east of the pond. The latter were stretching from north to south and were meant to cut across an assumed way leading towards the island (Fokt 2012, 310; see also Fig. 2 in this paper).

From among all the excavation trenches, only exploration of the trench II/2007 brought negative results, that is no anthropogenic layers upon the natural subsoil and below the recent humus; only one mobile find (a tiny potsherd, probably of late medieval origin) was found there. In the trenches I/07 and IV/09 various layers - in some of which fragments of late medieval pottery and metal objects resided were registered, which were heaped up by the inhabitants of the abandoned village in order to heighten the island and the dam. However, neither cultural layers sensu strictiori, nor any spurs of buildings were discovered both on island and to the northeast from it. However, in the largest sets of sounding trenches on both sites 3A (trenches III/07 with annexes and 


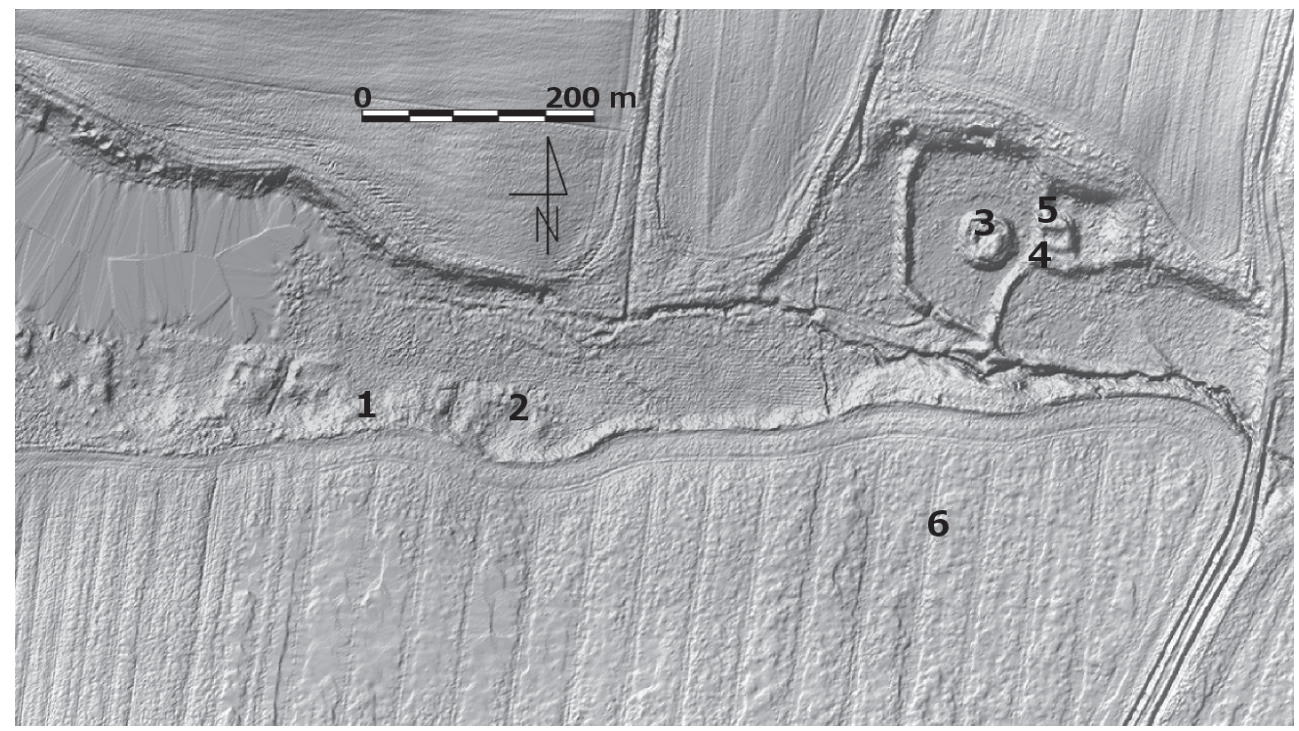

Fig. 2. Gębczyce, pow. strzeliński (Strzelin county), site 3: Situation of excavation trenches upon an DTM of the site. Scale $1: 5000$ (source of the DTM: COGiK K. Fokt, M. Legut-Pintal). 1. Site 3A, trenches III and V with annexes. 2. Site 3A, trench II. 3. Site 3B, trench I. 4. Site 3B, trenches VI-VII with annexes. 5. Site 3B, trench IV. 6. Site 3B, location of the grossus Pragensis found in 2008. - Obr. 2. Gębczyce, okres Střelín (Strzelin county), poloha 3: umístění archeologických sond vynesené na digitální model terénního reliéfu. Měŕítko 1:5000 (zdroj digitálního modelu terénního reliéfu: COGiK vypracovali: K. Fokt, M. Legut-Pintal). 1 - sídliště 3A, sondy III a V s rozšířením. 2 - sídliště 3A, sonda II. 3 - sídliště 3B, sonda I. 4 - sídliště $3 \mathrm{~B}$, sondy VI-VII s rozšířením. 5 - sídliště $3 \mathrm{~B}$, sonda IV. 6 - sídliště $3 \mathrm{~B}$, místo nálezu pražského groše nalezeného roku 2008.

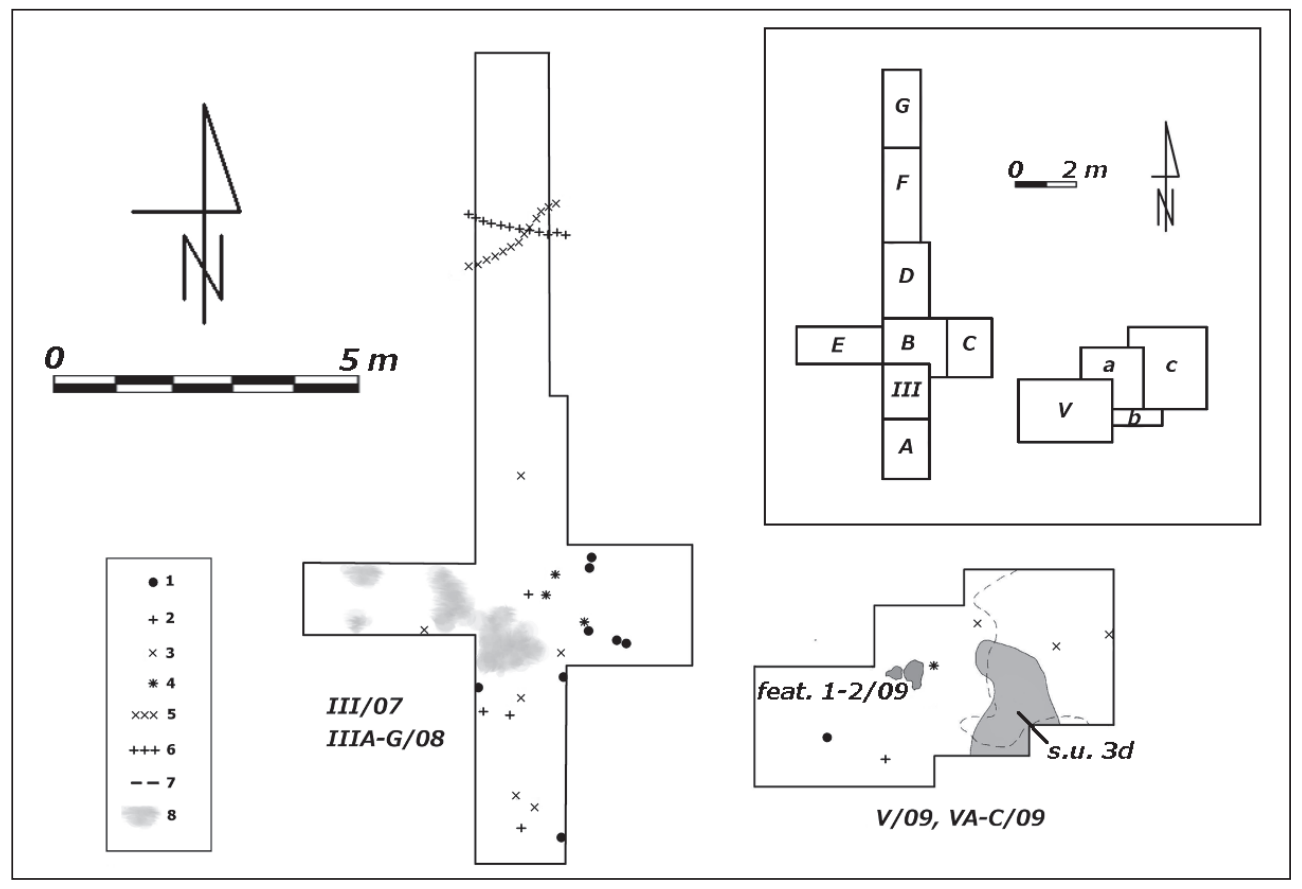

Fig. 3. Gębczyce, pow. strzeliński (Strzelin county), site 3: Numbering of the trenches III and V with annexes (scale $1: 400$ ) and planigraphy of finds and features registered in them (scale $1: 200$ ); elaborated by K. Fokt according to the field documentation. 1. Postholes. 2. Metal items discovered in the s.u. 2. 3. Metal items discovered in the s.u. 3. 4. Metal items discovered in the contact zone of the s.u. 2 and 3. 5. Northern boundary of the s.u. 3. 6. Northern boundary of the s.u. 4. 7. The range of the stone paving. 8. Agglomerations of charcoal. - Obr. 3. Gębczyce, okres Střelín (Strzelin county), poloha 3: číslování sond III a V s rozšířením (měřítko $1: 400$ ); zanesení polohy př́slušných nálezů a objektů (měřítko 1 : 200); vypracoval: K. Fokt podle terénní dokumentace. 1 - sloupové nebo kůlové jamky. 2 - kovové předměty nalezené ve vrstvě 2.3 - kovové předměty nalezené ve vrstvě 3.4 - kovové př̀edměty nalezené na rozhranní vrstev 2 a 3.5 - severní hranice vrstvy 3.6 - severní hranice vrstvy 4.7 - plocha s kamenným dlážděním. 8 - koncentrace uhlíků. 
V/09 with annexes) and 3B (trenches VI-VII/09 with annexes) some more interesting anthropogenic relics were registered, which documented the existence of the medieval settlement.

The stratigraphy of the central part of the site $3 \mathrm{~A}$ was simple. Directly upon the natural clay sediment (s.u. 4), a 2-18 cm thick, dark and fat cultural layer was registered (s.u. 3), consisting of clayish residue rich in organic fraction, containing pieces of charcoal. Upon it, directly below the recent humus layer (s.u. 1), a brownish, humic accumulation layer was observed (s.u. 2). There were also a few anthropogenic features registered in all the excavated area of the site 3A: nine postholes constituting no regular structure and 3 shallow pits of irregular shape, of which two (feat. no. 1-2/09) were only $1-3 \mathrm{~cm}$ deep and 10-20 cm long (see Fig. 3). The third one, registered as stratigraphic unit no. $3 \mathrm{~d}$ and documented only partially, was at the same time the largest. It was characterized by fat, clayish and organic filling generally similar to the cultural layer (s.u. 3), from which it was, in fact, not separated by any sharp limit. The pit in which the layer $3 \mathrm{~d}$ was deposited was only 1-4 cm deep.

The stratigraphy registered in the main set of excavation trenches on the site 3B (trenches VI-VII/09 with annexes) was far more complicated. Generally, three stages of settlement were registered. In the first one, a few levelling layers of different characteristics were deposited on the site upon the natural clay. Some of them (s.u. 4a, 7) comprised of considerable amount of organic material mixed with clay and contained many mobile finds; others (s.u. 5, $5 \mathrm{a}, 3 \mathrm{c}$ ) were composed mostly of clay and very few finds were found therein. Above all the leveling layers deposited in the first stage of settlement registered on the site $3 \mathrm{~B}$ two anthropogenic features were documented: a fireplace and a stone paving (see Fokt 2012, fig. VI.4 left). In the second phase of settlement development, relics of the previous stage were covered with a humic residue mixed with clay (s.u. 3), upon which, in the northern part of the excavated space (trench VI/09), a stone paving was registered (see Fokt 2012, 175, fig. VI.4 right and 176, fig. VI.6).

The above described strata, which were accumulated in the 1st and 2nd stages of settlement development, were covered with a brownish humic layer (s.u. 2). In the central part of the excavated space, upon the s.u. 2 and right beneath the recent humus and forest bed, two sections of stone foundations were discovered (see Fokt 2012, 134-135, fig. V.6-V.8). They were both running from west to east, being round $0,9 \mathrm{~m}$ broad. In order to discover the western boundary of the northern section of stone construction, an annex numbered VIIb was opened, in which the western edge of the foundation was discovered. Especially in this, northern section of stone foundation larger stones were laid on its inner and outer edges, the inside of it being filled with smaller stone material. The form of the foundation described above suggests that once it used to bear some wooden construction (see Fokt 2012, 133-135). Its localization allows to hypothesize that it was the road leading to the island, which would well correspond with the terrain configuration visible in field and recognizable on the DTM (see Fig. 2).

The excavation on both parts of the site (3A and 3B) brought to light rich assemblages of mobile finds, most of which comprised of ceramics. The oldest horizon of settlement, represented by the stratigraphically lowest features on both parts of the site (s.u. 3d on the site $3 \mathrm{~A}$ and the heart discovered in the trench VI/09 on the site 3B), should be probably attributed to the earliest stage of settlement regulated on the terms of Ius Theutonicum on the Strzelin Heights, that is, the 2 nd half of the 13 th century. The mobile inventory of that phase is represented by pieces of wheeled pottery made in technology typical for the final stage of the early medieval period and also ornamented in a way correspondent to the dawn of the early Middle Ages. Pieces of pottery of that sort are known only from the oldest anthropogenous layers of the site; all other ceramic finds may be safely attributed to the late medieval period, namely the 14 th through beginning of the 15 th centuries (see Fokt 2010, 271-273, 274; 2012, 311). Generally the assemblage of ceramics found in Gębczyce was older than the mass of ceramic finds from the Gromnik castle, dating from the mid-15th century (see on that briefly Fokt 2012, 311). Among the discovered pottery sherds pieces of pots prevailed; there were, however, also other forms represented (see Fokt Piekalski 2011, 415-416), as jugs (on the site 3A), bottles, bowls and a tripod-pan (only on the site 3B). Most of ceramic finds of late medieval technotype was made using materials and techniques typical for

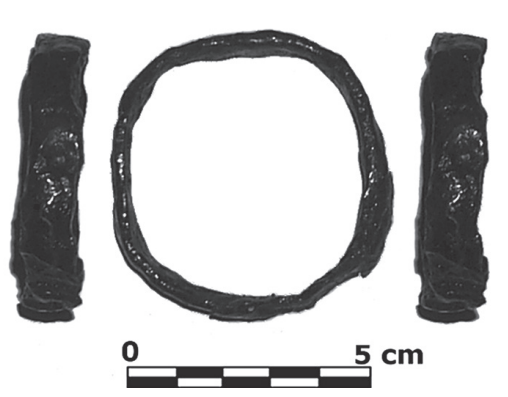

Fig. 4. Gębczyce, pow. strzeliński (Strzelin county), site 3A: a ferrule for fixing a scythe's blade on a shank (inv. no. 73). Scale 1 : 2 (photo and elaboration K. Fokt). - Obr. 4. Gębczyce, okres Střelín (Strzelin county), poloha 3A: kování upevňující čepel kosy na násadě (inv. č. 73). Měřítko $1: 2$. Foto a úprava: K. Fokt. 


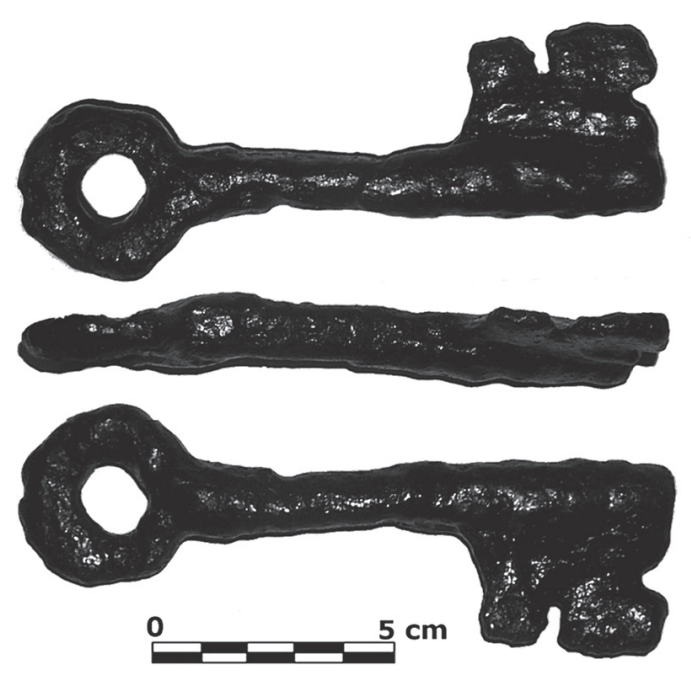

Fig. 5. Gębczyce, pow. strzeliński (Strzelin county), site 3A: a key discovered in the s.u. 3 (inv. no. 96). Scale $1: 2$. (photo and elaboration K. Fokt). - Obr. 5. Gębczyce, okres Střelín (Strzelin county), poloha 3A: klíč nalezený ve vrstvě 3 (inv. č. 96). Měŕítko 1 : 2. Foto a úprava: K. Fokt.

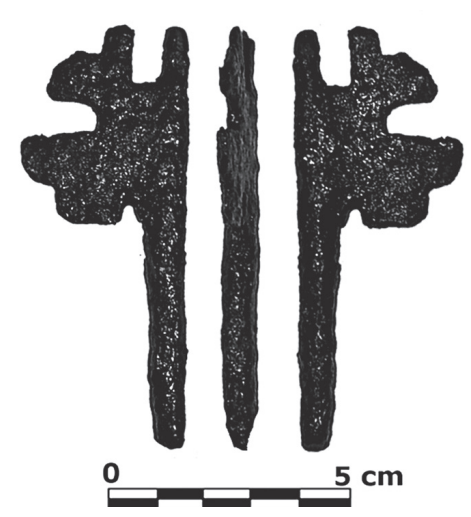

Fig. 6. Gębczyce, pow. strzeliński (Strzelin county), site 3A: a part of a key discovered in the s.u. 3 (inv. no. 118). Scale $1: 2$ (photo and elaboration K. Fokt). - Obr. 6. Gębczyce, okres Střelín (Strzelin county), poloha 3A: zlomek klíče nalezený ve vrstvě 3 (inv. č. 118). Měřítko $1: 2$. Foto a úprava: K. Fokt.

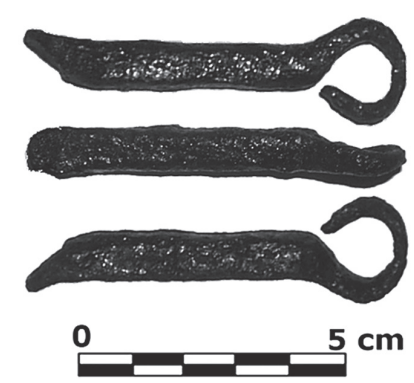

Fig. 7. Gębczyce, pow. strzeliński (Strzelin county), site 3A: a part of a horse bit (inv. no. 81). Scale $1: 2$ (photo and elaboration K. Fokt). - Obr. 7. Gębczyce, okres Střelín (Strzelin county), poloha 3A: zlomek koňského udidla (inv. č. 81). Měŕítko $2: 1$. Foto a úprava: K. Fokt. the pottery classified by Pawet Rzeznik (2005) as type C2; there were, however, also other types represented: B0, B1 and C1.

During all three seasons of excavation, on the site $3 \mathrm{~A}$ (the village) there were discovered 26 , and on site $3 \mathrm{~B}$ (the manorial part of the settlement): 37 iron finds. Among the iron items from the site $3 \mathrm{~A}$ there were 5 fragments of knives, 2 cells of chains, 2 parts of mowing tools (see Fokt - Piekalski 2011, 412; Fokt 2012, 199, fig. VII.2 and fig. 4 in the present paper), 1 whole (Fig. 5) and 1 incomplete key (Fig. 6), 1 segment of a chain, 1 piece of horse bit (Fig. 7), 1 incomplete horseshoe, 1 lump of melted iron (see Fokt 2012, 244, fig. VIII.8), 1 fragment of a staple and 1 nail. On the site $3 \mathrm{~B}$ there were found up to 7 nails, 3 iron rings (presumably cells of chains), 2 punches (see one of them by Fokt 2010, 275, fig. 5, no. 2 and Fokt 2012, 242, fig. VIII.6), 2 knives (one of them drawn by Fokt 2010, 275, fig. 5, no. 1), 1 whole (Fokt 2012, 243, fig. VIII.7) and one incomplete horseshoe, 3 horseshoe-nails (two of them: Fokt 2012, 243, fig. VIII.7), 1 hook (part of a hinge or a staple) and 1 arrowhead ${ }^{2}$.

Certainly the most interesting find made of non-ferrous metal discovered in the settlement complex Gębczyce 3 was a piece of a silver coin, found in the year 2008 on a field, to the south from the site $3 \mathrm{~B}$ (situation of the finding was depicted on the Fig. 2; the fragment of the coin itself: Fig. 8 in this paper $)^{3}$. It was a part of a grossus Pragensis of Charles IV of Luxembourg, king of Bohemia (1346-1378). Unfortunately, this accidental finding cannot be put in any relation with the stratigraphy of the site 3 in Gębczyce; nevertheless, the coin was most probably lost nearby the village yet in the time of its existence. Apart from this unique finding, also a piece of not specified artifact made of copper alloy was uncovered in the s.u. 5 in the trench VIIa/09 on the site 3B.

There were also a few finds made of stone discovered on both parts of the settlement complex Gębczyce 3, among them four artefacts interpretable as hones, made of local quartz-sericite slate ${ }^{4}$. Two of them originated from the site $3 \mathrm{~A}$ and two from the site $3 \mathrm{~B}$. They were all discovered in stratigraphic contexts related to the earlier stages of the existence of the rural settlements on both sites, comprising the settlement complex Gębczyce 3: in the s.u. 3 respec-

2 All iron finds were cleaned off and preserved in the Laboratory for Archaeometry and Preservation of Finds of the Institute of Archeology of the Wrocław University.

3 The coin was discovered by dr. Aleksandra Pankiewicz during her visit on the site and its preliminary attribution provided by professor Krzysztof Jaworski; it should be also mentioned here that both these scholars provided much help and support to the excavation conducted in Gębczyce.

4 The typology and provenience of the stone material were determined by dr. Ewa Lisowska, to whom the authors would like to express their gratitude. 


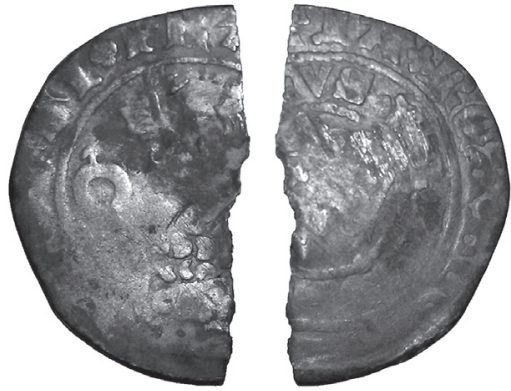

Fig. 8. Gębczyce, pow. strzeliński (Strzelin county), site 3B: a piece of a grossus Pragensis of Charles IV discovered in 2008 (inv. no. 81). Photo and elaboration by K. Fokt. Scale 2 : 1. - Obr. 8. Gębczyce, okres Střelín (Strzelin county), poloha 3B: zlomek pražského groše Karla IV. Nalezený roku 2008 (inv. č. 81). Měřítko 2 : 1. Foto a úprava: K. Fokt.

tively $3 / 2$ on the site $3 \mathrm{~A}$ and in the layers $3 / 4 \mathrm{a}$ on the site $3 \mathrm{~B}$. The findings of hones made of local stone material proves that quartz-sericite slate from the so called "Jegłowa series" - exploited either in the still-existent villages Jegłowa and Krzywina or in one of the deserted settlements in the northern part of the Strzelin Heights - was not only exported to the Silesian towns (Wrocław, Legnica, Nysa: see Lisoweska 2013, 209, with further references), but also used locally.

The scope of excavation conducted on the site 3 in Gębczyce and the state of elaboration of their results allow only to bring some small insights into the form and structure of the deserted village core, related probably to the primitive location of the village Geppersdorf. It consisted probably of two separate parts, registered as the sites $3 \mathrm{~A}$ and $3 \mathrm{~B}$, the latter being the manorial, and the former - the peasant settlement. Especially interesting would be the continuation of research on the site 3B. It is not only rich in various mobile finds, but also offers a unique possibility to study relics of primordial space organization and architecture which are surprisingly well-preserved as three-dimensional structures visible on the ground surface (ponds, dams, island). This reflection was only confirmed by the analysis of the DTM based on airborne laser scanning, made available to the broader public in 2014 (cf. further and Fig. 2). There are a few landforms which may be interpreted as preserved parts of the settlement visible on the surface of the area, located to the west from the part of the site 3A already subdued to investigation (see Fig. 2). It seems, however, that most of the structures related to the peasant settlement on the site $3 \mathrm{~A}$ were already destroyed. On the contrary, the site $3 \mathrm{~B}$ offers huge variability of convex structures which are well preserved and could illustrate the economy and topography of a local manor on the Strzelin Heights.

\section{The second stage of the research on Strzelin Heights (2014): the northeastern part of the region}

In the year 2014 new opportunities to broaden and deepen the agenda of research on the abandoned villages of the Strzelin Heights emerged, thanks to the official state project ISOK (system of the country's protection against extreme hazards), which included publishing of DTM based upon airborne laser scanning through the platform geoportal.gov .pl. ${ }^{5}$ Study of the published DTM of the northern part of the Strzelin Heights revealed that in a saddle between the main ridge of the Heights, stretching from the Gromnik Mt. northwards, and the massif of Garnczarek there are well-preserved and clearly visible relics of a deserted rural settlement (see the preliminary report: Fokt - Legut-Pintal 2014). According to the information provided by Oscar Vug $(1890,286)$, the newly discovered settlement should be identical to the abandoned village named Goschwitz, of which some relics (interpreted as wells) were known to the local inhabitants yet at the very end of the $19^{\text {th }}$ century.

There may be distinguished three main groups of material vestiges of the deserted village that are recognizable on the DTM. The first and most interesting one comprises of concave and convex land forms, which are destructs of the buildings which used to exist on the intravillan plots. The preliminary estimation of those features allows to suppose that at least on four of those plots - all of them situated in the northern row (frontage) - the main buildings were quinpartite (or even larger) peasant houses. These multi-functional housing establishments were aimed with their gable ends towards the village green (pol. nawsie, germ. Anger). They were two-wings buildings with four rooms (among them, certainly a chamber and a hall) arranged in line perpendicularly to the axis of the village core and the fifth (a granary?) neighboring with the fourth to the east.

Another group of features recognizable in the DTM are spurs of delimitations which surround the whole village core and divide the intravillan plots. It would rather be pointless to speculate about the measurement of those plots basing only upon the DTM. It is, however, possible to hypothesize on the metrology of the whole village core, which is rectangular and resembles typical disposition of a Silesian Angerdorf. In the preliminary report concerning the discovery of the settlement (Fokt - Legut-Pintal 2014, 223) an attempt of reconstruction of the acreage of the village core was presented, according to which it was to be around 10 ha large. Such an acreage of the deserted

5 Official website of the Project ISOK: http://www.isok.gov.pl 


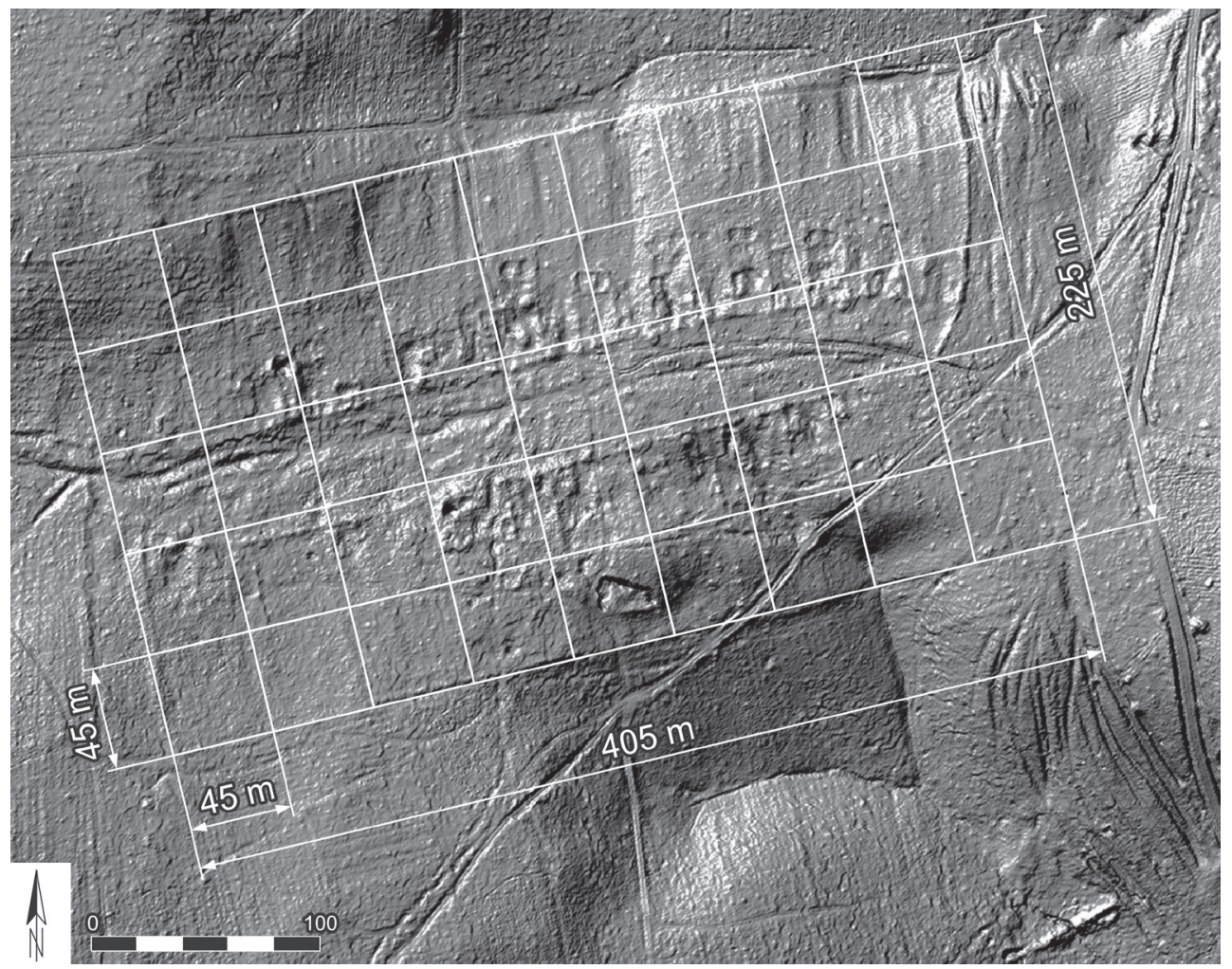

Fig. 9. Strzelin Heights, pow. strzeliński (Strzelin county): Perfect 45 meter (1 chain) grid manually adjusted to fit the settlement layout (source of the DTM: COGiK; elaboration M. Legut-Pintal). - Obr. 9. Střelínská pahorkatina, okres Střelín: ideální čtvercová sít (délka čtverce $45 \mathrm{~m}$ ) ručně přizpůsobená a proložená skrz půdorys zaniklé vsi (zdroj digitálního modelu terénního reliéfu: COGiK; vypracovala: M. Legut-Pintal).

village core seems to be overestimated as a result of inaccurate approximation of its length. In order to eliminate this defect, another attempt of area estimation was made. The extreme plot on the western edge of the southern frontage, "protruding" from the rectangle of the village core, was eliminated from the estimation in order to reconstruct the basic, regularly rectangular measurement. It turned out that the basic rectangle - or rather parallelogram - of the village core had quite regular dimensions, with its longer sides measuring $405 \mathrm{~m}$ and the shorter sides being $225 \mathrm{~m}$ long. Both those values reflect the basic module of measurement, which would be ca. $45 \mathrm{~m}$ long. The same module is easily recognizable in the plots of the central part of the village core, which are twice so deep and divided by the $45 \mathrm{~m}$ wide village green. This basic module of ca. $45 \mathrm{~m}$ length should be identified as the chain (pol. sznur, germ. Seil) which was used at the location of the village - that is, ca. 10 rods (pol. pretty, germ. Ruten), each ca. 4,5 m long. In that case, the acreage of the village core should be estimated on exactly 15 acres (pol. morgi, germ. Morgen - not 18, as it has been supposed in the preliminary report - with longer side measuring 9 and the shorter one 5 chains (see Fig. 9).
The third group of anthropogenous land forms recognizable on the DTM and probably related to the deserted village are the features lying outside the village core: delimitations of field plots, vestiges of field cultivation, old tracks preserved as road gullies (pol. wacwozy drożne, germ. Hohlwege) and quarries. It is difficult to identify those, which would be related to the deserted village. Nonetheless, an attempt to distinguish some of those features as effects of the activities of the inhabitants of the abandoned Goschwitz, even basing upon sole DTM, would not be hopeless. Respective reasoning should rest upon three groups of information that may be read out of the DTM: lengths of basic measurement units (estimated above), elimination of linear land forms not harmonizing geometrically with the village core, and, on the contrary, distinguishing those that do not correspond with present courses of roads, paths and plot limits.

Apart from the features identifiable as relics of the village Goschwitz, vestiges of another deserted late medieval settlement were luckily identified on the DTM of the northeastern part of the Strzelin Heights. These were detected in the upper valley of Jegłówka stream, where actually no one would expect good preservation of any land forms of medi- 
eval origin because of establishing of ponds in this area in the modern era. Nevertheless, careful observation of the DTM revealed that on the northern slope of upper Jegłówka valley, in the lowest part of the Garnczarek massif, a group of linear, convex landforms exists which may be identified as relics of another deserted village core. The features recognizable on the DTM are probably spurs of its outer delimitation. Signs of divisions of intravillan plots are, unfortunately, less recognizable. The part of the village core discovered in Jegłówka valley which was not destroyed by younger human activities is less regular than the village core identified by us above as Goschwitz. Nonetheless, probably the same measurement unit was used there - a ca. $45 \mathrm{~m}$ long chain (chord) and the northern side of the non-existent village core was ca. 5 chains long. According to the situation of the village core found in Jegłówka valley, it should be probably identified as material relics of the village Buchwald.

On both sites, identified by us operationally as material relics of the village Goschwitz and Buchwald, pieces of pottery analogous to the ones excavated on the site Gębczyce were found, which supports the identifications presented above. More knowledge on them will be obtained through further investigation. At the moment, attempts have been made to put both unique sites in the Strzelin Heights under legal protection by their registration as immobile monuments in the Lower Silesian Bureau for Protection of Antiquities (DWUOZ) in Wrocław, in order to prevent the deterioration of their condition. It seems obvious that those two sites, with their exceptionally well preserved relics of medieval buildings, delimitations and infrastructure, should become a subject of interdisciplinary study.

The paper was submitted by authors on 7 fanuary 2015. See also Fokt - Legut-Pintal 2016.

\section{Bibliography}

\section{Primary sources: editions}

Pater et al. ed. 1991. Liber fundationis claustri sanctae Mariae Virginis in Heinrichow, czyli Ksiega Henrykoweska, elaborated and translated by R. Grodecki, 2nd, edition (with facsimile of the source), Wrocław.

SR. Regesten zur schlesischen Geschichte, ed. C. Grünhagen, K. Wutke, E. Randt, Codex Diplomaticus Silesiae, vol. 7, 16, 18, 22, 29, 30, Breslau 1875-1930.

SUB. Schlesisches Urkundenbuch, ed. H. Appelt, W. Irgang, vol. 1-6, Köln - Wien - Graz 1963-1998.

\section{Secondary sources}

Brucksch, E. 1926: Ein verschollenes Dorf, Heimatblätter für den Kreis Strehlen 4/1.

Dabrowski, H. 1956: Uformowanie się wielkiej własności feudalnej klasztoru Cystersów w Henrykowie, Roczniki Historyczne 21: 1953-1954, 109-149.

Domański, G. 2002: Ślęża w pradziejach i średniowieczu, Wrocław.

Eistert, K. 1935-36: Untergegangene Dorfer im Kreise Strehlen, Heimat-Blätter für den Kreis Strehlen 13/1-3, 14/1-6.

Eistert, K. 1937: Drei Wüstungen am Rummelsberge, Heimat-Blätter für den Kreis Strehlen 15/1-2.

Eistert, K. 1938: Bergbau im Kreise Strehlen in früheren Jahrhunderten, Heimat-Blätter für den Kreis Strehlen 16/3-4.

Fokt, K. 2010: Pierwszy etap badań opuszczonych osad wiejskich na Wzgórzach Strzelinskich, Śląskie Sprawozdania Archeologiczne, vol. 52, 263-278.

Fokt, K. 2012: Późnośredniowieczne osadnictwo wiejskie na Dolnym Śląsku w świetle badań archeologicznych, Kraków.

Fokt, K. - Legut-Pintal, M. 2014: Wzgórza Strzelińskie (zanikła średniowieczna wieś), Silesia Antiqua, vol. 49, 221-224.

Fokt, K. - Legut-Pintal, M. 2016: Zanikłe wsie Wzgórz Strzelińskich: stan i perspektywy badań. In: Wieś zaginiona : stan i perspektywy badań, Chorzów, 113-145.

Fokt, K. -Piekalski, f. 2011: Current problems of research on production, processing, storage and distribution of food in the medieval rural environment of Lower Silesia. In: J. Klápště - P. Sommer. (eds.): Ruralia VIII: Processing, storage, distribution of food: Food in the medieval rural environment, Turhhout, 409-420.

Gaik, E. - Gołaszewski, f. - Stelmach, R. - Zarzycka, H. Majewski, W. 2005: Przeworno: historia i teraźniejszość, Przeworno.

Geschwendt, F. 1922: Vino bei Zobten, Schlesische Geschichtsblätter 15/2-3, 40-41.

Golinski, M. 2007: Dzieje zamku na Gromniku. In: K. Jaworski - A. Pankiewicz (eds.): Gromnik. Z dziejów zasiedlenia i zagospodarowania szczytu, Wrocław, 9-24.

Görlich, F. X. 1853: Geschichte der Stadt Strehlen in Preußisch-Schlesien, Breslau.

Hensel, W. - Hilczer-Kurnatowska, Z. - Łosińska, A. 1995: Studia i materiały do osadnictwa Wielkopolski wczesnohistorycznej, vol. 7, Poznań.

Kajzer, L. 1996: Wstęp do archeologii historycznej w Polsce, Łódź.

Korta,W. 1964: Rozwój wielkiej własności feudalnej na Śląsku do połowy XIII wieku, Monografie Śląskie vol. 8, Wrocław - Warszawa - Kraków.

Lisowska, E. 2013: Wydobycie i dystrybucja surowców kamiennych we wczesnym średniowieczu na Dolnym Śląsku, Wrocław.

Maleczyński, K. 1960: Śląsk w okresie od połowy XII do połowy XIV w. In: K. Maleczyński (ed.): Historia Śląska, vol. 1 (until 1763), part 1 (until the mid-14th cent.), Wrocław, 238-617.

Niemiec, D. 2012: Badania archeologiczne we Frydmanie na Spiszu w latach 2009-2010. In: U. Janicka-Krzywda K. Słabosz-Palacz (ed.): Z dziejów Frydmana, 12-14. 
Parczewski, M. 1974: Przyczynki do dziejów najstarszego osadnictwa w Karpatach polskich, Acta Archaeologica Carpathica, vol. 14, 69-78.

Parczewski, M. 2007: Nowe początki starego Dubiecka, Rzeszów.

Pokleweski, T. 1987: Źrodła archeologiczne dotyczące wsi późnośredniowiecznej - zabudowa, gospodarka, kultura materialna, mieszkańcy, Rocznik Przedsiębiorstwa Państwowego Pracownie Konserwacji Zabytków, vol. 1987 (printed 1988), issue 2, 31-41.

Poklewski-Koziett, T. 2011: Uwagi o programie badań archeologicznych nad średniowieczną wsią w Polsce. In: W. Świętosławski (ed.): Terra incognita: Archeologiczne studia nad późnośredniowieczną i nowożytną wsią, Acta Archaeologica Lodziensia, no. 57, Łódź 13-22.

Przybytowicz, O. M. 2016: Klasztor klarysek w Strzelinie uposażenie, darowizny i dochody. Przyczynek do standardu życia wspólnoty w świetle prawa zakonnego i dokumentów, Śląski Kwartalnik Historyczny Sobótka $71 / 2,19-46$.

Romiński, W. 1969: Badania ratownicze na osadzie z okresu wpływów rzymskich w Głębinowie, pow. Nysa, Terenowe badania archeologiczne na Opolszczyźnie, 18-19.

Rutkowska-Płachcinska, A. 1965: Strzelin, Ścinawa i Grodków: nieudane możnowładcze założenia targowe w XIII wieku, Studia z dziejów osadnictwa, vol. 3, 39-67.

Rzeźnik, P. 2005: Ceramika naczyniowa z wykopu nr 1 na Placu Nowy Targ. In: C. Buśko (ed.): Wschodnia strefa Starego Miasta we Wrocławiu w XII-XIV wieku. Badania na Placu Nowy Targ, Wrocław, 97-110.
Stelmach, R. (ed.) 1991: Katalog dokumentów przechowywanych w Archiwach Państwowych Dolnego Śląska, vol. 1: until 1300, Wrocław.

Świętosławski, W. 2011: Słowo wstępne. In: W. Świętosławski (ed.): Terra incognita: Archeologiczne studia nad późnośredniowieczną i nowożytną wsią, Acta Archaeologica Lodziensia, no. 57, Łódź, 5.

Tobiasz, M. 1964: Odkrycie w lesie falsztyńskim, Wierchy 33, 206-207.

Vug, O. 1890: Schlesische Heidenschanzen, ihre Erbauer und die Handelsstrassen der Alten. Ein Beitrag zur deutschen Vorgeschichte, vol. 2, Grottkau.

Żemigata, M. 2011: Badania archeologiczne wsi średniowiecznej w Polsce (lata 1945-2010). In: W. Świętosławski (ed.): Terra incognita: Archeologiczne studia nad późnośredniowieczną i nowożytną wsią, Acta Archaeologica Lodziensia, no. 57, Łódź 7-12.

\section{Krzysztof Fokt}

Uniwersytet Jagiellonski w Krakowie,

Wydziat Prawa i Administracji, Pracownia Wydawnictw Źródłowych

krzysztof.fokt@uj.edu.pl

Maria Legut-Pintal

Politechnika Wrocławska,

Katedra Historii Architektury, Sztuki i Techniki

maria.legut-pintal@pwr.edu.pl 